\title{
Fluktuasi Harga Cabai Merah Di Masa Pandemi Covid 19 di Kota Jambi
}

\author{
Siti Abir Wulandari \\ Program Studi Agribisnis Fakultas Pertanian Universitas Batanghari \\ J1. Slamet Riyadi-Broni, Jambi. 36122. Tel. +6274160103 \\ e-mail : abir_wulandari@yahoo.com
}

\begin{abstract}
The Covid-19 pandemic has stopped community activities. Since last March, various aspects of life in this country have been suspended animation to remote areas including Jambi Province. The stretching routine that fades during the corona pandemic has slowed down the economy. In Jambi, the indicator for the decline in the economic graph can be seen from the shift in the value of inflation / deflation, which reflects movements in the prices of goods / services on the market. A horticultural commodity that is widely developed and is one of the people's needs is red chili. This has resulted in the level of demand for red chili that continues to occur, and at certain times the price of red chili has increased, for example in the new year or during the Eid al-Fitr. This study aims to see the development of the price of large red chilies and curly red chilies and to analyze the differences in price fluctuations of large red chilies and curly red chilies in the city of Jambi. This research was carried out during the Covid 19 pandemic. The study focused on the description of the price of large and curly red chilies in the Angso Duo market, the Talang Banjar market and the Simpang Pulai market. The data collected is a time series in the form of data on the price development of chilies from January to June 2020. The data collected is secondary data in this study, obtained from literature and related agencies, namely the Department of Industry and Trade, Market Service, Central Agency Statistics. In this study using a desk study data collection method. The results showed that in general at the beginning of 2020 there was a difference in the price of curly red chilies in Jambi City from Rp. 40,467, - / $\mathrm{kg}$ and there was a decrease to Rp. 15,647, - / $\mathrm{kg}$ in June with a decrease of about $61 \%$. This price reduction also applies to large red chilies, which decreased by 55\% from Rp. 30,500, - / kg in January to Rp. 13. 647, - / kg in June. The coefficient of variance of large red chilies is 0.38 while curly red chilies are 0.40. The coefficient of variance in plain view shows a difference where the coefficient of variance of the price of curly red chilies is higher than the coefficient of variance of the price of large red chilies. but statistically these two variance coefficients do not show a significant difference.
\end{abstract}

Keywords: Fluctuation, Price, Chili

\begin{abstract}
Abstrak. Pandemi Covid-19 menghentikan gerak aktivitas masyarakat. Sejak Maret lalu berbagai sendi kehidupan di negeri ini seperti mati suri hingga ke pelosok daerah termasuk Propinsi Jambi Aktivitas rutin yang memudar di saat pandemi corona membuat laju ekonomi melambat. Di Kota Jambi, indikator menurunnya grafik perekonomian bisa terlihat dari pergeseran nilai inflasi/deflasi yang mencerminkan pergerakan harga-harga barang/jasa di pasaran. Komoditas hortikultura yang banyak dikembangkan dan merupakan salah satu kebutuhan masyarakat adalah cabai merah. Hal ini mengakibatkan tingkat permintaan cabai merah yang terus terjadi, dan pada waktu tertentu harga cabai merah mengalami kenaikan, misalnya pada tahun baru atau pada saat hari raya Idul Fitri. Penelitian ini bertujuan untuk melihat perkembangan harga cabai merah besar dan cabai merah keriting serta menganalisis perbedaan fluktuasi harga cabai merah besar dan cabai merah keriting di kota Jambi. Penelitian ini dilaksanakan pada pada masa pandemic Covid 19. Kajian difokuskan pada gambaran harga cabai merah besar dan keriting di pasar angso Duo, Pasar Talang Banjar dan Pasar Simpang Pulai. Data yang dikumpulkan adalah time series berupa data perkembangan harga cabai dari bulan Januari sampai bulan Juni 2020. Data yang dikumpulkan merupakan data sekunder dalam penelitian ini, diperoleh dari literatur - literatur dan instansi - instansi terkait yaitu Dinas Perindustrian dan Perdagangan, Dinas Pasar, Badan Pusat Statistik. Dalam penelitian ini menggunakan metode pengumpulan data desk study. Hasil penelitian menunjukkan bahwa secara garis besar di awal tahun 2020 terdapat perbedaan harga cabai merah keriting di Kota Jambi dari Rp. 40.467,- / kg dan terjadi penurunan menjadi Rp.15.647,- / kg di bulan Juni dengan penurunan sekitar 61\%. Penurunan harga ini juga berlaku untuk cabai merah besar yang mengalami penurunan sebesar $55 \%$ dari Rp. 30.500,- $/ \mathrm{kg}$ di bulan Januari menjadi Rp. 13. $647,-/ \mathrm{kg}$ di buan Juni. Koefisien varians cabai merah besar sebesar 0,38 sedangkan cabai merah keriting sebesar 0,40 . Koefisien varians secara kasatmata menunjukkan perbedaan dimana Koefisien varians harga cabai merah keriting lebih tinggi dibandingkan dengan Koefisien varians harga cabai merah besar. tetapi secara statistik kedua koefisien varians ini tidak menunjukkan perbedaan yang nyata.
\end{abstract}

Kata Kunci : Fluktuasi, Harga, Cabai

\section{PENDAHULUAN}

Pandemi Covid-19 menghentikan gerak aktivitas masyarakat. Sejak Maret lalu berbagai sendi kehidupan di negeri ini seperti mati suri. Tak hanya di Ibukota Jakarta, kekhawatiran terhadap virus berbahaya itu merebak hingga ke penjuru negeri termasuk Propinsi Jambi Aktivitas rutin yang memudar di saat pandemi corona membuat laju ekonomi melambat. Di Kota Jambi, indikator menurunnya grafik perekonomian bisa terlihat dari pergeseran nilai inflasi/deflasi. Mencerminkan pergerakan harga-harga barang/jasa di pasaran.

Komoditas hortikultura yang banyak dikembangkan dan merupakan salah satu kebutuhan masyarakat adalah cabai merah. Cabai adalah salah satu komoditas sayuran unggulan nasional dengan daya adaptasi dan nilai ekonomi tinggi. Cabai termasuk komoditas strategis pertanian yang mendapat perhatian serius dari pemerintah dan pelaku usaha 
karena kontribusinya terhadap perekonomian nasional. Kebutuhan cabai untuk kota-kota besar sekitar 800.000 ton/tahun atau sekitar 66.000 ton/bulan. Untuk memenuhi kebutuhan bulanan masyarakat perkotaan diperlukan luas area panen cabai sekitar $11.000 \mathrm{ha} / \mathrm{bulan}$, sedangkan pada saat perayaan hari besar dan acara syukuran luas area panen cabai yang harus tersedia berkisar antara 12.100- 13.300 ha/bulan (Anwarudin et.al, 2015). Karena banyak digunakan sebagai bumbu masakan, ramuan obat, dan sebagai campuran dalam industri makanan dan minuman. Hal ini mengakibatkan tingkat permintaan cabai merah yang terus terjadi, dan pada waktu tertentu harga cabai merah mengalami kenaikan, misalnya pada tahun baru atau pada saat hari raya lebaran (Nurvitasari et.al, 2018).

Pengembangan komoditas cabai merah lingkup nasional memiliki empat sasaran, yaitu (1) Ketersediaan cabai merah yang lebih merata sepanjang tahun; (2) Stabilisasi harga cabai merah di pasaran; (3) Pengurangan impor cabai merah; dan (4) Peningkatan ekspor cabai merah. Untuk mencapai sasaran tersebut maka salah satu upaya yang dilakukan adalah peningkatan produksi untuk memenuhi kebutuhan masyarakat terhadap cabai merah yang semakin meningkat (Swastika et.al, 2017). Salah satu kota di Propinsi Jambi yang memproduksi cabai merah adalah Kota Jambi dengan luas lahan lahan cabai merah sebesar 15,70 hektar, dan produksi sebesar 81,64 ton dan produktivitas yaitu sebesar 5,2 Ton/Hektar pada tahun 2017 (Dinas Pertanian Tanaman Pangan, Hortikultura, dan Peternakan Provinsi Jambi 2018).

Sejak lama pasar tradisional memegang peranan penting dalam memajukan dan menggerakkan pertumbuhan ekonomi rakyat. Fungsi penting pasar tradisional di samping sebagai muara dari produk - produk masyarakat di sekitarnya (lokal), juga merupakan lapangan kerja yang sangat bermanfaat bagi masyarakat. Hasil - hasil pertanian yang di hasilkan petani secara langsung dapat di bawa ke pasar. Untuk membawa hasil-hasil pertanian tersebut di butuhkan tenaga kerja. Tenaga kerja tidak semata membawa hasil petani ke pasar, namun ketika para pedagang membeli hasil - hasil pertanian, pedagang membutuhkan tenaga angkut, tenaga kerja yang sekaligus dimanfaatkan sebagai kuli panggul. Pada hakikatnya pasar tradisional bergerak pada sektor informal, oleh karena itu siapa saja memiliki peluang untuk mendapatkan pekerjaan di pasar (Palaskas and Harris, 1991 dalam Anindita, 2004). Suatu komoditas bisa sampai ke konsumen dengan adanya pasar. Kota Jambi memiliki beberapa pasar tradisional yaitu Pasar Angso Duo, Pasar Talang Banjar, Pasar Simpang Pulai dan lain - lain.

Secara keseluruhan peranan pemasaran pada komoditas cabai merah memberikan kontribusi penting dalam peningkatan kinerja usahatani seperti halnya komoditas hortikultura pada umumnya, mengingat sifat unik komoditas hortikultura secara umum seperti mudah rusak, mudah busuk, volumenious, produksinya bersifat musiman, kebanyakan dibutuhkan dalam keadaan segar dan konsumsi terjadi sepanjang tahun. Pada saat panen secara empiris dilapangan seringkali dijumpai bahwa para petani produsen tampaknya tetap saja menghadapi fluktuasi harga, dan akses untuk dapat memperoleh harga yang lebih tinggi diperoleh para pedagang, oleh karena itu, peningkatan produksi komoditas pertanian termasuk cabai merah perlu diiringi dengan perbaikan pada system pemasarannya, sehingga pihak petani sebagai produsen komoditas ini diharapkan dapat memperoleh bagian harga yang memadai bagi peningkatan usahataninnya ( Agustian dan Setiajie A, 2008).

Secara historis harga itu ditentukan oleh pembeli dan penjual melalui proses tawar menawar, sehingga terjadilah kesepakatan harga tertentu. Pada mulanya harga menjadi faktor penentu, tetapi dewasa ini faktor penentu pembelian semakin bervariasi, sehingga faktor selain harga juga banyak berperanan dalam keputusan pembelian. Semua variabel yang terdapat pada bauran pemasaran merupakan unsur biaya kecuali variabel harga yang satu-satunya merupakan unsur pendapatan (revenue).

Harga-harga memainkan peranan sentral dalam teori ekonomi, yaitu dalam membimbing dan mengarahkan produksi dan konsumsi. Dari sisi pemawaran faktor-faktor yang mempengaruhi harga produk pertanian adalah keputusan-keputusan produksi usahatani, cuaca, hama dan penyakit, luas areal panen dan impor pangan. Sedangkan dari sisi permintaan faktor-faktor yang menentukan adalah pendapatan konsumen, harga-harga, selera dan pilihan, jumlah penduduk, dan ekspor. Selanjutnya kegiatan tataniaga juga dapat mempengaruhi harga-harga usahatani melalui subsidi harga, pembatasan areal, kebijaksanaan perdagangan dan sebagainya (Nasarudin W, 1999).

Cabai merah merupakan salah satu komoditas yang memiliki fluktuasi harga yang cukup besar. Fluktuasi harga cabai merah dapat disebabkan oleh besarnya jumlah penawaran dan besarnya jumlah permintaan. Semakin tinggi jumlah penawaran maka harga akan rendah, sedangkan semakin sedikitnya jumlah penawaran harga akan semakin meningkat (ceteris paribus). Harga cabai merah yang berfluktuasi ini merupakan fenomena yang berulang-ulang sepanjang tahun. Fenomena lonjakan harga cabai merah menjadi pantauan oleh pemerintah sebab dapat mengakibatkan inflasi bagi perekonomian (Nurvitasari et.al, 2018).

Penelitian ini bertujuan untuk melihat perkembangan harga cabai merah besar dan cabai merah keriting serta menganalisis perbedaan fluktuasi harga cabai merah besar dan cabai merah keriting di Kota Jambi 


\section{METODOLOGI PENELITIAN}

Penelitian ini dilaksanakan pada pada masa pandemic Covid 19. Kajian difokuskan pada gambaran harga cabai merah besar dan cabai merah keriting di pasar angso Duo, Pasar Talang Banjar dan Pasar Simpang Pulai. Adapun data yang dikumpulkan dalam penelitian ini adalah perkembangan harga komoditas cabai merah besar dan keriting di masing-masing pasar. Data yang dikumpulkan adalah time series berupa data perkembangan harga cabai dari bulan Januari sampai bulan Juni 2020 dan berskala ukur rasio. Skala rasio adalah suatu skala yang memiliki sifat - sifat skala nominal, skala ordinal, dan skala interval dilengkapi dengan titik nol absolut dengan makna empiris. Karena terdapat angka nol, maka pada skala ini dapat dibuat perkalian atau pembagian. Angka pada skala menunjukkan ukuran yang sebenarnya dari objek/kategori diukur. Data yang dikumpulkan merupakan data sekunder, diperoleh dari literatur - literatur dan instansi - instansi terkait yaitu Dinas Perindustrian dan Perdagangan, Dinas Pasar, Badan Pusat Statistik dan instansi terkait lainnya. Dalam penelitian ini menggunakan metode pengumpulan data desk study. Metode desk study yaitu cara pengumpulan data dan informasi melalui pemeriksaan dan analisis data dan informasi yang menggunakan data sekunder, baik berupa dokumen - dokumen internel/eksternal.

Analisis data yang digunakan dalam penelitian ini untuk mengetahui harga cabai merah besar dan cabai merah keriting adalah menggunakan analisis deskriptif. Untuk menggambarkan fluktuasi harga digunakan koefisien keragaman, yaitu perbandingan antara standar deviasi dan harga rata - rata (mean) dinyatakan dalam persen (\%). Tujuan dilakukan perhitungan koefisien keragaman dalam suatu rangkaian data, semakin kecil nilai koefisien semakin seragam data tersebut, begitu pula sebaliknya semakin besar nilai koefisien keragaman, semakin tidak seragam data tersebut.

Variasi data dapat dihitung dengan menggunakan rumus sebagai berikut (Nasarudin W, 1999) :

$$
\mathrm{CV}=\frac{s}{\bar{x}} \times 100 \%
$$

Dimana $: \mathrm{s}=$ simpangan baku (standard deviasi)

$$
\mathrm{s}=\sqrt{\sum\left(x_{i}-\bar{x}\right)} \text { rataan (mean) nilai data }
$$

Dimana : $\mathrm{x}=$ nilai data

$$
\mathrm{n}=\Sigma \text { data }
$$

\section{HASIL PENELITIAN}

Pasar adalah tempat terjadinya transaksi antara produsen dan konsumen atas barang - barang ekonomi. Pasar didefinisikan sebagai Tempat bertemunya pembeli dan penjual. Dengan kata lain komponen suatu pasar meliputi pembeli, penjual, dan fasilitas pasar. Pada kenyataannya, pasar bukan hanya merupakan tempat dimana pembeli dan penjual saling bertemu. Pasar merupakan suatu tempat dimana mereka dapat melakukan transaksi dengan bantuan fasilitas yang ada seperti telepon faksimile, internet, dan lain-lain tanpa harus saling bertemu di tempat tertentu.

Pyndick dan Rubinfield (2000) dalam Anindita 2016, menunjukkan pentingnya luas dari suatu pasar. Luas pasar ini ditentukan oleh batas-batas (boundaries) baik secara geografis maupun dalam hal kisaran dari suatu produk (range of products). Batas Secara geografis memiliki arti bahwa harga suatu komoditi di suatu daerah akan berbeda dengan harga produk yang sama di daerah yang lain. Sementara itu, batas kisaran dari suatu produk menunjukkan kisaran dari jenis produk yang dijual di pasar.

Analisis permintaan dan penawaran adalah aspek penting dalam mempelajari pemasaran. Analisis ini bertujuan untuk menentukan bagaimana ketersediaan komoditi di pasar, bagaimana komoditi tersebut dibutuhkan, serta bagaimana harga ditentukan. Kurva rencana penawaran statis merupakan hubungan antara harga dan jumlah barang yang ditawarkan di pasar dalam periode waktu tertentu jumlah produk pertanian atau komoditas yang ditawarkan untuk dijual ini bergantung pada harga dan variabel lain yang dapat berpengaruh terhadap jumlah yang ditawarkan. Untuk mempermudah analisisnya, faktor lain akan dianggap tetap atau ceteris paribus.

Terdapat beberapa faktor penting yang dapat menggeser penawaran atau supply antara lain:

1. Perubahan harga input

2. Harga komoditi lainnya yang berhubungan

3. Perubahan teknologi

4. Perubahan harga produk gabungan atau joint product

5. Ramalan penjualan pada harga dimasa yang akan datang

6. Cuaca

Permintaan merupakan kekuatan yang mendorong komoditi bergerak melalui saluran pemasaran. Secara teoritis, permintaan merupakan keseluruhan jumlah dari suatu komoditi atau produk yang akan dibeli oleh konsumen pada 
berbagai tingkat harga dalam jangka waktu tertentu dan syarat tertentu. Sedangkan faktor lain yang mempengaruhi permintaan dianggap konstan atau ceteris paribus. Permintaan yang dianggap efektif terdiri dari keinginan untuk mendapatkan dan kemampuan membayar komoditi. Jika keinginan atau kemampuan untuk membeli tidak ada maka permintaan di suatu pasar tidak akan efektif. Kemampuan beli seseorang erat kaitannya dengan tingkat pendapatan dan juga harga barang. Harga dan pendapatan (jumlah uang) akan mempengaruhi kemampuan beli dan keinginan untuk mendapatkan barang terealisasi (Amaliawiati L, Murni A, 2014)

Berbagai macam teknik digunakan untuk menentukan harga produk dalam transaksi secara individu maupun digunakan untuk menemukan harga keseimbangan pasar. Tomek dan Robinson (1981) serta Schaffner, Schroder dan Earle (1998) dalam Anindita (2016) menganggap hal tersebut sebagai mekanisme atau penentuan harga mekanisme itu mereka bagi menjadi dua kategori yaitu negosiasi secara individu, pasar yang terorganisir, rumus penentuan harga, dan dikendalikan dan tawar-menawar secara kelompok atau kolektif.

Secara individu, para petani mempunyai sedikit kesempatan untuk mengontrol atau mengendalikan harga. Mereka tidak seperti banyak perusahaan yang memproduksi barang-barang non pertanian kesempatan untuk melakukan hal seperti itu dibatasi oleh perusahaan perusahaan yang memproduksi produk khusus atau produk yang berbeda serta dibatasi oleh perusahaan yang memiliki kekuatan monopoli Di mana perusahaan harus menghadapi kurva permintaan yang tidak elastis sempurna. Dalam konsep ekonomi, penentuan harga suatu perusahaan ditentukan pada umumnya hanya dapat mencapai normal profit sedangkan suatu perusahaan yang berada pada pasar yang bersaing tidak sempurna seperti monopolistik Oligopoli dan Monopoli dapat mencapai profit. Pada kondisi normal profit harga ditentukan oleh keseimbangan permintaan dan penawaran produk di pasar, sedangkan for profit terjadi saat perusahaan atau produsen mampu menentukan harga di pasar karena berada pada kondisi pasar persaingan tidak sempurna

Sifat kompetitif dari pasar produk pertanian menyulitkan para petani atau siapapun yang memasarkan produk pertanian untuk mengendalikan mengendalikan harga dan secara khusus ingin mempertahankannya secara substansial agar berada diatas tingkat keseimbangan kompetitif tanpa dukungan pemerintah. Jika harganya dinaikkan, para petani dan perusahaan proses harus menerima usaha pengendalian terhadap produksi. Satu-satunya alternatif terhadap pembatasan produksi adalah mengembangkan outlet sekunder untuk komoditi yang memiliki surplus atau meminta pemerintah untuk membeli kuantitas apapun yang tidak dapat dijual dengan harga yang lebih tinggi.

Untuk mengukur atau menentukan struktur pasar, pertama kali yang dilakukan adalah mengumpulkan data tentang pangsa pasar atau market share dalam persen. Pengumpulan data ini dilakukan dengan sensus agar seluruh pelaku pasar teridentifikasi. Pangsa pasar adalah persentasi dari total penjualan pada satu target pasar yang diperoleh dari suatu perusahaan disini potensi pasar akan dibagi dengan jumlah penjualan.

Pasar Angso Duo adalah pasar tradisional terbesar di Kota Jambi. Pasar yang berada di pinggir Sungai Batang hari dan sudah ada sejak tahun 1960-an. Secara. Luas areal pasar tradisional Angso Duo yaitu 7,2 ha. Terdapat 2.688 jumlah pedagang yang berada di dalam areal. Lokasi pasar Angso Duo terletak di Jl. Sultan Thaha Kelurahan Beringin, Kecamatan Pasar Jambi, Kota Jambi. Pasar Talang Banjar adalah pasar tradisional No.2 terbesar, sebagai pasar distribusi bagi pasar-pasar tradisional lainnya yang ada di Kota Jambi. Pasar talang banjar memiliki pedagang sebanyak 1.198 pedagang (orang) dengan luas lahan 1,12 ha. Jl. Rangkayo Pingai Kecamatan Jambi Timur, Kota Jambi. Pasar Simpang Pulai adalah pasar tradisional yang ada di kota jambi. Pasar ini berada di Simpang Pulai Kelurahan Solok Sipin Kecamatan Telanaipura Kota Jambi.

\section{Perkembangan Harga Cabai Merah Besar Dan Cabai Merah Keriting Di Di Kota Jambi}

Cabai merupakan komoditas penting bagi perekonomian yang banyak diusahakan. Kenaikan harga cabai turut menyumbang besarnya inflasi bahan makanan yang terjadi di Indonesia. Harga bahan makanan yang stabil merupakan harapan masyarakat. Cabai termasuk salah satu bahan pangan yang mempunyai harga sangat berfluktuasi. (Nauly D, 2016). Komoditas ini sangat sensitif terhadap cuaca sehingga berakibat pada fluktuasi pasokan dan fluktuasi harga, sehingga berakibat cukup besar terhadap inflasi. Fluktuasi produksi cabai, selain disebabkan oleh musim, juga oleh terkonsentrasinya pusat-pusat produksi hanya di wilayah atau pulau tertentu, sementara konsumen cabai tersebar di hampir seluruh wilayah atau pulau di Indonesia (Supriadi H dkk, 2018).

Secara garis besar di awal tahun 2020 terdapat perbedaan harga cabai merah keriting di Kota Jambi. Harga cabai merah keriting di bulan Januari sebesar Rp. 40.467,- $/ \mathrm{kg}$ dan terjadi penurunan menjadi Rp.15.647,- $/ \mathrm{kg}$ di bulan Juni dengan penurunan sekitar $61 \%$ selama memasuki pandemic covid 19 yang dimulai dari bulan Maret hingga bulan Juni (Gambar 1) . Harga ini mewakili tiga pasar besar yaitu Pasar Angso Duo, Pasar Talang Banjar dan Pasar Simpang Pulai dan terdapat persamaan harga di dua pasar yaitu Pasar Simpang Pulai dan Pasar Talang Banjar. Penurunan harga ini juga berlaku untuk cabai merah besar yang mengalami penurunan sebesar $55 \%$ dari Rp. 30.500,/kg di bulan Januari menjadi Rp. 13. 647,-/kg di bulan Juni. Sebagaimana Sudarsono (1990), menyatakan tenaga beli seseorang tergantung atas dua unsur pokok yaitu pendapatan yang dibelanjakan dan harga barang yang dikehendaki. Apabila jumlah pendapatan yang dibelanjakan oleh seseorang berubah maka jumlah barang yang diminta juga akan 
berubah demikian juga halnya harga barang yang dikehendaki juga dapat berubah. Secara matematis pengaruh perubahan harga dan pendapatan terhadap jumlah yang diminta dapat diketahui secara serentak.

Sejalan dengan pernyataan diatas, selama pandemic Covid -19 Pemerintah Kota Jmabi menghimbau masyarakat untuk tidak banyak melaukan aktivitas diluar rumah, selalu menjaga jarak dan tidak berkumpul. Hal ini juga berakibat menurunnya permintaan dari industri makanan seperti warung, rumah makan dan kafe-kafe ditambah dengan diberlakukannya pembatasan social yang berdampak semakin berkurangnya konsumen yang berbelanja dipasar-pasar tradisional di Kota Jambi. Meskipun penjualan bahan makanan secara daring mulai marak tetapi tidak seramai apabila konsumen membeli secara langsung di pasar. Selain itu selama pandemic pendapatan masyarakat juga menurun karena adanya pemutusan hubungan kerja (PHK), penutupan tempat penjualan seperti mall dll yang dibatasi hanya menjual bahan makanan saja, indutri pakaian juga menurun, Wedding Organizer (WO) dan catering juga mengalami penurunan karena tidak perbolehkan mengadakan acara atau jamuan untuk pernikahan sehingga permintaan indutri makanan yang membutuhkan cabai sebagai bahan baku dalam skala besar seperti pembuatan rendang, dendeng dan lainnya menurun drastis.

Dalam kurun waktu enam bulan terakhir, harga cabai merah besar tertinggi yaitu sebesar Rp. 40.862,-/kg yang terjadi di bulan Februari untuk pasar Talang Banjar dan Pasar Simpang Pulai sedangkan harga di pasar Angso duo lebih rendah karena merupakan pasar induk terbesar di Kota Jambi dengan harga cabai besar merah yaitu Rp. 32.000,$/ \mathrm{kg}$. sedangkan harga terendah mencapai Rp. 13.647,-/kg di ketiga pasar. Untuk cabai merah keriting harga tertinggi juga terjadi di bulan Februari untuk kurun masa 6 bulan terakhir yaitu sebesar Rp. 43.517,- di pasar Talang Banjar dan Pasar Simpang Pulai dan harga di pasar Angso Duo yang berkisar Rp.36.000,-/kg dan terdapat persamaan harga cabai merah keriting terendah di tiga pasar yang mencapai Rp. 15.647,-/kg. Selain harga cabai merah itu sendiri, terdapat beberapa faktor lain yang mempengaruhi permintan cabai merah keriting. Permintaan cabai merah keriting yang berfluktuatif dapat disebabkan oleh faktor ekonomi dan faktor sosial. Faktor ekonomi yang mempengaruhi adalah harga (harga barang itu sendiri dan harga barang lain yang dapat menjadi pengganti atau penggenapnya) dan pendapatan.

Menurut Prastowo et al. (2011) dalam Fina Y (2019), harga komoditas yang terbentuk pada tingkat akhir atau konsumen sangat tergantung pada panjang pendeknya saluran distribusi. Semakin pendek saluran distribusinya maka harga komoditas semakin menurun begitupun sebaliknya. Pada penelitian Palar et al. (2016) dalam Fina Y (2019) salah satu faktor yang mempengaruhi harga cabai yaitu harga komoditas pengganti (substitusi). Komoditas pengganti adalah komoditas yang dapat menggantikan fungsi komoditas lain sehingga harga komoditas pengganti dapat mempengaruhi permintaan komoditas yang dapat digantikannya (Sugiarto, 2000; Palar et al., 2016). Apabila harga komoditas utama meningkat maka penjual akan meningkatkan jumlah komoditas pengganti yang ditawarkan. Penjual berharap, konsumen akan beralih dari komoditas utama ke komoditas pengganti yang ditawarkan, karena harganya lebih rendah (Palar et al., 2016 dalam Fina Y, 2019).

Jumlah permintaan cabai relatif tetap sepanjang waktu, sedangkan produksi berkaitan dengan musim tanam. Maka dari itu pasar akan kekurangan pasokan kalau masa panen raya belum tiba. Dalam kesempatan seperti ini beruntung bagi petani yang dapat memproduksi cabai sepanjang tahun. Mengingat permintaan cabai merah relatif stabil sepanjang tahun, maka managemen produksi perlu diatur, agar tidak terjadi fluktuasi baik produksi maupun harga. Pola produksi cabai merah selama ini sangat tidak beraturan sehingga yang semestinya usahatani ini sangat menguntungkan, seringkali mendatangkan kerugian bagi petani maupun konsumen (Alexander, 2011 dalam Suprayitno, 2015).

Harga rata-rata cabai merah keriting di tiga pasar di Kota Jambi selama bulan Januari adalah sebesar Rp. 40.467,/kg dan meningkat di bulan Februari menjadi Rp. 41.011,-/kg. memasuki bulan Maret hingga bulan Juni rata-rata harga cabai merah keriting terus menurun dari Rp.30.200,-/kg menjadi Rp. 18.156,-/kg di bulan April, Rp. 17.000,$/ \mathrm{kg}$ di bulan Mei dan menyentuh harga rata-rata Rp. 15.647,-/kg di Bulan Juni. Menurunnya harga cabai ini juga di dukung dengan pengaturan masa panen yang mendekati bulan puasa dan lebaran (akhir bulan Mei) oleh petani dikarenakan biasanya terjadi lonjakan harga yang tinggi menjelang lebaran namun tidak di duga terjadinya pandemic covid yang menyebabkan kurangnya permintaan cabai merah keriting di pasaran dimana pada saat itu produksi cabai petani melimpah sehingga terjadi ketidakseimbangan antara supply dan demand karena stok cabai merah keriting meningkat dan tidak terjadi kenaikan harga pada cabai merah keriting. Untuk lebih jelasnya dapat dilihat pada Gambar 1.

Hal yang sama juga berlaku untuk cabai merah besar dimana di tiga pasar di Kota Jambi selama bulan Januari rata-rata harga cabai merah besar adalah sebesar Rp. 30.500,-/kg dan meningkat dibulan Februari menjadi Rp. 37.908,$/ \mathrm{kg}$. memasuki bulan Maret hingga bulan Juni rata-rata harga cabai merah besar terus menurun dari Rp.28.000,- $/ \mathrm{kg}$ menjadi Rp. 16.156,-/kg di bulan April, Rp. 15.000,-/kg di bulan Mei dan menyentuh harga rata-rata Rp. 13.647,-/kg di Bulan Juni. Untuk lebih jelasnya dapat dilihat pada Gambar 2. 


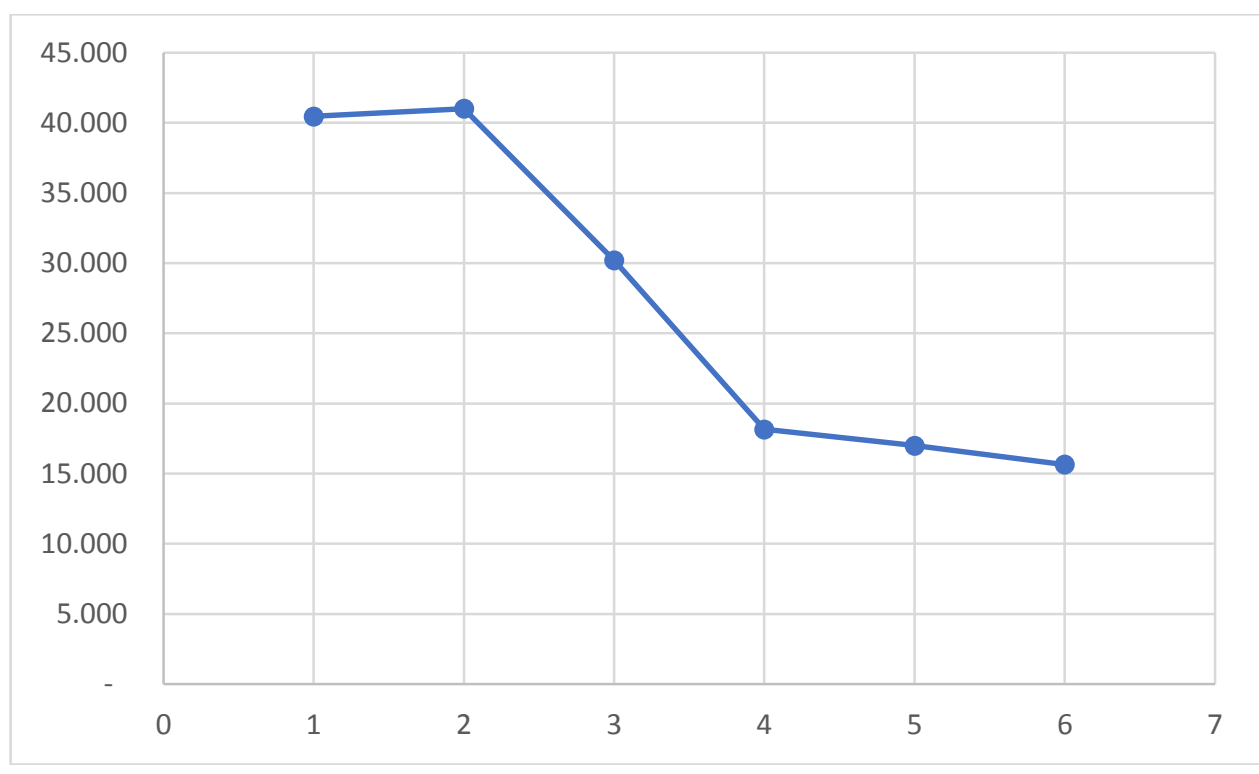

Gambar 1. Perkembangan Harga Cabai Merah Keriting Di Kota Jambi Tahun 2020.

Sumber : Data penelitian diolah, 2020.

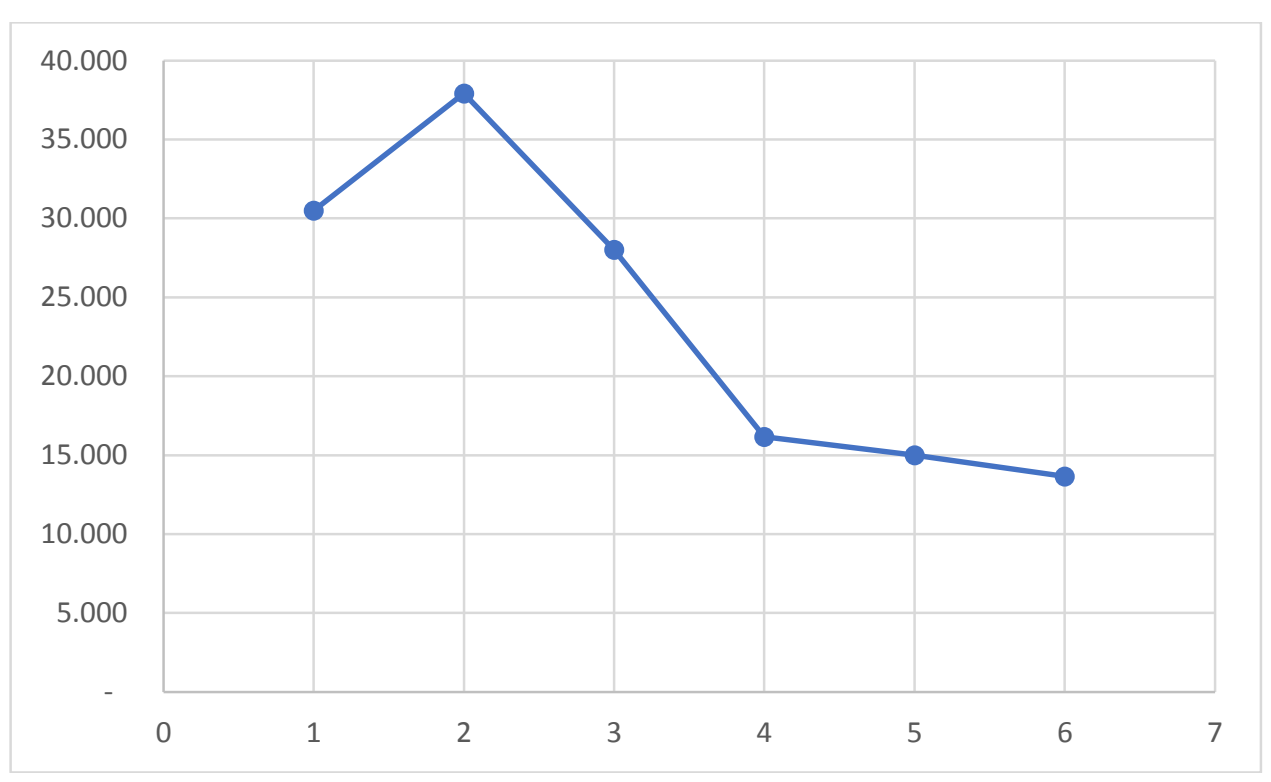

Gambar 2. Perkembangan Harga Cabai Merah Besar Di Kota Jambi Tahun 2020 Sumber : Data penelitian diolah, 2020.

Hal berbeda terjadi di tahun 2019, pada bulan Juni berdasarkan pantauan harga cabai merah keriting di Pasar Angso Duo Jambi telah menembus angka Rp. 65.000/kg (Dinas Perindustrian dan Perdagangan (Disperindag) Propinsi Jambi, 2020). Menyikapi gejolak harga cabai yang rutin terjadi tiap akhir tahun, Dinas Ketahanan Pangan Provinsi Jambi bersama Kementerian Pertanian melakukan stabilitasi harga cabai serta menyiapkan serangkaian solusi atas gejolak harga cabai, yakni jangka panjang dan jangka pendek. Untuk jangka pendek maka diintensifkan perdagangan antar pulau dan simulasi distribusi cabai. Simulasi yang dimaksud adalah daerah yang surplus komoditas cabai memasok daerah yang kekurangan pasokan yang melibatkan BUMD tiap daerah, Bulog dan Swasta,

Adanya ketidakstabilan harga cabai merah berhubungan erat dengan kondisi produksi maupun penawaran cabai merah. Menurut Firdaus (2012), beberapa faktor yang menyebabkan penawaran barang pertanian tidak elastis adalah barang pertanian tergantung pada faktor alam sehingga produksi bersifat musiman dan kapasitas memproduksi sektor pertanian cenderung mencapai tingkat tinggi tidak terpengaruh oleh perubahan permintaan. Fluktuasi produksi cabai merah disebabkan oleh perubahan luas panen cabai merah. Harga dan produksi cabai merah mengalami trend perubahan yang berfluktuatif dan meningkat setiap bulan. Trend peramalan harga dan produksi memiliki pola perubahan yang saling beriringan (Nurvitasari et.al, 2018). 
Selanjutnya Nurvitasari et.al, (2018) menyatakan faktor produksi dan penawaran merupakan faktor yang dapat menentukan harga cabai merah. Faktor-faktor yang berpengaruh nyata terhadap penawaran cabai merah di Kabupaten Jember secara bersama-sama yakni produksi cabai merah bulan sebelumnya, harga cabai merah bulan sebelumnya, harga cabai rawit bulan sebelumnya, luas panen cabai merah, dan curah hujan dengan prosentase pengaruh variabel sebesar 55\%. Faktor yang signifikan berpengaruh parsial terhadap penawaran cabai merah di Kabupaten Jember adalah produksi cabai merah bulan sebelumnya dan luas panen.

Selama pandemic covid 19 ini tidak terjadi lonjakan harga pada komoditi cabai baik cabai merah besar maupun cabai merah keriting. Sesuai dengan pernyataan (Marliah. 2011) bahwa kebutuhan akan cabai merah terus meningkat sejalan dengan meningkatnya jumlah penduduk dan berkembangnya industri makanan yang membutuhkan bahan baku cabai. Kebutuhan cabai yang semakin meningkat ini akan meningkatkan agregat di pasar. Naik turunnya permintaan bisa dipengaruhi oleh banyak faktor diantaranya faktor harga barang itu sendiri, harga barang pengganti (subtitusi) dan barang pelengkap (komplementer) juga mempengaruhi permintaan (Sukirno, 2013). Hal ini sesuai dengan pendapat (Noviasari, 2014 dalam S.R. Hadi, et.al 2016) yang menyatakan bahwa komoditi yang dapat dijadikan sebagai barang substitusi diantaranya cabai kering, cabai rawit merah, cabai rawit hijau, saus sambal dan lada.

Selama pandemi ini dikarenakan tidak diizinkannya penyelenggaraan pesta atau kenduri karena takut terjangkit virus corona sehingga permintaan cabai menurun drastis dan stok atau penawaran cabai meningkat yang berakibat terjadi ketidakseimbangan antara permintaan dan penawaran cabai merah baik besar maupun keriting sehingga harga tidak mengalami peningkatan. Tanpa penanganan atau pengolahan yang cepat dan tepat, kelebihan produksi cabai pada saat panen raya akan menyebabkan harga jualnya makin turun dan akhirnya cabai dibuang atau tidak dapat diolah lagi.

Produk pertanian berbeda dengan produk non pertanian karena produk pertanian mempunyai masalah pemasaran yang unik. Karakteristik dari produk pertanian rata-rata mudah rusak, musiman, membutuhkan ruangan yang banyak dan tidak seragam. Sifat mudah rusak (perishability) merupakan karakteristik penting yang harus diperhatikan dari produk pertanian karena ini dapat mempersulit pekerjaan pemasaran seperti yang telah kita ketahui, kesegaran adalah salah satu ukuran dari kualitas buah-buahan dan sayuran, sehingga produk pertanian memerlukan penanganan khusus dalam pemasaran agar cepat terjual. Setiap pengunduran waktu yang dilakukan berarti kualitas akan turun dan sebagian berat akan turun; pada akhirnya ini akan mempengaruhi harga jual yang diterima produsen (Anindita, 2016).

Adanya fluktuasi peningkatan maupun penurunan produksi cabai merah setiap bulannya disebabkan oleh adanya pengaruh musim pada usahatani cabai merah, yakni musim kemarau dan musim penghujan. Produksi cabai merah pada musim penghujan biasanya cenderung rendah sebab banyak gangguan hama maupun penyakit yang menyebabkan cabai merah tidak berproduksi optimal. Selain itu, fluktuasi produksi cabai merah ini juga dipengaruhi oleh besarnya jumlah luas panen pada usahatani cabai merah (Nurvitasari et.al, 2018).

Kenaikan harga cabai sangat tergantung pada musim panen dan musim tanam serta pengaruh iklim. Disamping itu kenaikan harga juga berkaitan dengan kegiatan pemasaran. Bila dibandingkan dengan harga didaerah konsumen harga cabai didaerah produsen lebih rendah. Beberapa faktor yang mempengaruhi diantaranya faktor angkutan, rendahnya daya tahan cabai, dan daya beli masyarakat yang rendah (Santika, 1999 dalam Fajri et.al, 2017). Harga cabai di beberapa kota besar, umumnya meningkat pada bulan Oktober - Desember dan Pebruari - April. Hal ini sesuai dengan kenyataan, pada bulan tersebut musim hujan lebat, sehingga tidak banyak orang bertanam cabai. Akibatnya hasil panen (persediaan) cabe rendah (paceklik), sedangkan permintaan selalu bertambah ( Sunaryono, 1988 dalam Suprayitno 2015).

Sebelum memasuki puasa ramadhan biasanya terjadi lonjakan harga cabai karena sebagai tradisi masyarakat melayu menyambut bulan puasa mereka berlomba-lomba mengadakan syukuran arwah sehingga permintaan cabai merah keriting dan besar naik, namun karena masyarakat takut keluar rumah sehingga juga terjadi penurunan permintaan dan tidak terjadi lonjakan harga cabai merah. Menjelang hari raya idul fitri juga tidak terjadi lonjakan harga cabai merah. Sesuai dengan pernyataan Sumarsono 2007, bahwa hukum permintaan menerangkan tentang hubungan antara harga dengan jumlah barang yang diminta. Salah satu jenis cabai yang memiliki permintaan tinggi adalah cabai merah keriting. Jumlah ketersediaan dengan jumlah kebutuhan cabai merah keriting tidak selalu seimbang. Hal ini disebabkan karena tidak stabilnya jumlah cabai yang diproduksi dan jumlah permintaan konsumen yang berfluktuatif sehingga dapat memberikan dampak pada ketidakstabilan harga cabai dipasaran.

Perwakilan Bank Indonesia (BI) Provinsi Jambi mencatat transmisi dampak Covid-19 terhadap perekonomian Jambi, bahwa penyediaan makan dan minum turun 30 persen dan konsumsi terbatas pada pemenuhan dasar, transportasi serta perdagangan berkurang. Pertumbuhan ekonomi melemah dikarenakan daya beli menurun, investasi menurun, ekspor impor menurun, kemampuan belanja pemerintah juga menurun, Hasil Survei Pemantauan Harga (SPH) mingguan hingga minggu keempat bulan April 2020, menunjukkan terjadinya penurunan harga pada beberapa komoditas. Seperti cabai merah dan daging ayam ras dikarenakan melambatnya permintaan ditengah terjaganya pasokan selama bulan laporan (Ikbal F, 2020). 


\section{Fluktuasi Harga Cabai Merah Besar Dan Cabai Merah Keriting Di Kota Jambi}

Dari hasil perhitungan harga cabai merah besar dan keriting di Kota Jambi menunjukkan perbedaan koefisien varians . Koefisien variasi (CV) merupakan ukuran variasi yang bersifat relatif yang dapat digunakan untuk memperbandingkan beberapa himpunan data yang berbeda. Koefisien varians dipakai jika hendak membandingkan $\mathrm{S}$ dari dua distribusi frekuensi yang tidak mempunyai satuan pengukuran yang sama; tidak mempunyai X yang sama; dan hanya boleh dipakai jika skala pengukuran adalah rasio. Koefisien varians cabai merah besar sebesar 0,38 sedangkan cabai merah keriting sebesar 0,40. Koefisien varians secara kasatmata menunjukkan perbedaan dimana Koefisien varians harga cabai merah keriting lebih tinggi dibandingkan dengan Koefisien varians harga cabai merah besar. Hal ini menunjukkan bahwa fluktuasi harga di pasar tersebut lebih variatif pada cabai merah keriting dimana harga terendah dan harga tertinggi lebih jauh dibandingkan yang terjadi pada komoditas abe merah besar, tetapi secara statistik kedua koefisien varians ini tidak menunjukkan perbedaan yang nyata.

\section{KESIMPULAN}

1. Secara garis besar di awal tahun 2020 terdapat perbedaan harga cabai merah keriting di Kota Jambi dari Rp. $40.467,-/ \mathrm{kg}$ dan terjadi penurunan menjadi Rp.15.647,- $/ \mathrm{kg}$ di bulan Juni dengan penurunan sekitar $61 \%$. Penurunan harga ini juga berlaku untuk cabai merah besar yang mengalami penurunan sebesar $55 \%$ dari Rp. $30.500,-/ \mathrm{kg}$ di bulan Januari menjadi Rp. 13. 647,-/kg di buan Juni.

2. Koefisien varians cabai merah besar sebesar 0,38 sedangkan cabai merah keriting sebesar 0,40. Koefisien varians secara kasatmata menunjukkan perbedaan dimana Koefisien varians harga cabai merah keriting lebih tinggi dibandingkan dengan Koefisien varians harga cabai merah besar. tetapi secara statistik kedua koefisien varians ini tidak menunjukkan perbedaan yang nyata.

\section{DAFTAR PUSTAKA}

Agustian dan Setiajie A, 2008. Analisis Perkembangan Harga dan Rantai Pemasaran Cabai Merah di Jawa Barat. http://pse.litbang.pertanian.go.id/ind/pdffiles/MP_Pros_C4_2009.pdf

Amaliawiati L, Murni A, 2014. Ekonomika Mikro. PT. Refika Aditama. Bandung

Anindita R, Baladian N, 2016. Pemasaran Produk Pertanian. Penerbit Andi. Yogyakarta.

Anindita R, 2004. Pemasaran Hasil Pertanian. Papyrus. Surabaya.

Anwarudin, MJ, AL Sayekti, Aditia MK dan Yusdar. 2015. Dinamika Produksi dan Volatilitas Harga Cabai: Antisipasi Strategi dan Kebijakan Pengembangan.

https://media.neliti.com/media/publications/30886-ID-dinamika-produksi-dan-volatilitas-harga-cabaiantisipasi-strategi-dan-kebijakan.pdf

Dahlia Nauly, 2016. Fluktuasi Dan Disparitas Harga Cabai Di Indonesia. Jurnal Agrosains dan Teknologi, Vol. 1 No. 1 Juni 2016.

https://jurnal.umj.ac.id/index.php/ftan/article/view/1479/pdf

Dinas Perindustrian dan Perdagangan (Disperindag) Propinsi Jambi, 2020. Rekapitulasi Harian Harga Rata-Rata Beberapa Bahan Pokok Pangan Tahun 2020.

Dinas Pertanian Tanaman Pangan, Hortikultura, dan Peternakan Provinsi Jambi, 2018. Luas lahan Produksi dan Produktivitas Cabai Merah Di Propinsi Jambi.

Fajri R, T. Fauzi, Indra, 2017. Analisis Faktor-Faktor Yang Mempengaruhi Harga Cabai Merah Di Kota Banda Aceh. http://jim.unsyiah.ac.id/JFP/article/view/3754/4240

Fina Yuliawati, 2019. Faktor-Faktor Yang Mempengaruhi Harga Cabai Rawit Di Pasar Ngablak, Kabupaten Magelang. SEPA : Vol. 15 No.2 Februari 2019 https://jurnal.uns.ac.id/sepa/article/download/28134/pdf · PDF file

Ikbal Ferdiyal, 2020. BI Provinsi Jambi Mencatat Perekonomian dan Beberapa Sektor Menurun Akibat Covid-19 https://metrojambi.com/read/2020/04/30/53164/bi-provinsi-jambi-mencatat-perekonomian-dan-beberapasektor-menurun-akibat-covid19-/

Marliah, Marianti, dan Armi. 2011. Pertumbuhan Dan Hasil Beberapa Varietas Cabai Merah Pada Media Tumbuh Yang Berbeda-Beda. Jurnal ISSN/E-ISSN: 1907-2686/3597-9108. Banda Aceh. Universitas Syiah Kuala Darrusalam. Banda Aceh.

Nasruddin W, A Musyadar, 1999. Tataniaga Pertanian. Universitas Terbuka, Jakarta.

Nurvitasari ME, Suwandari A, Suciati LP, 2018. Dinamika Perkembangan Harga Komoditas Cabai Merah (Capsicum Annuum L) Di Kabupaten Jember. JSEP Vol 11 No. 1 Maret 2018.

https://www.google.com/url?sa=t\&rct=j\&q=\&esrc=s\&source=web\&cd=\&cad=rja\&uact=8\&ved=2ahUKEwjk 2uuTgbjsAhXlheYKHdpUB-

cQFjAAegQIBBAC\&url=https\%3A\%2F\%2Fjurnal.unej.ac.id\%2Findex.php\%2FJSEP\%2Farticle\%2Fdownlo ad\%2F5802\%2F5522\%2F\&usg=AOvVaw1XJhIQ1O5SLuxTFyglSJHr 
Pusat Informasi Harga Pangan Strategis Nasional. 2020. Perkembangan Harga Pangan. https://hargapangan.id/tabelharga/pasar-tradisional/daerah

Syahyuti, Sayaka B, 2020. Enam Bulan Pandemi: Permintaan Produk Pertanian Anjlok

http://pse.litbang.pertanian.go.id/ind/index.php/covid-19/berita-covid19/568-enam-bulan-pandemi-permintaanproduk-pertanian-anjlok

Soim A. 2019. BKP Kementan Gandeng Dinas Ketahanan Pangan Jambi Stabilkan Harga Cabai. https://tabloidsinartani.com/detail/industri-perdagangan/olahan-pasar/8946-BKP-Kementan-Gandeng-DinasKetahanan-Pangan-Jambi-Stabilkan-Harga-Cabai

S.R. Hadi, T. Ekowati, D. Sumardjono, 2016. Analisis Faktor - Faktor Yang Mempengaruhi Permintaan Cabai Merah Keriting Pada Rumah Tangga Di Kecamatan Banyumanik Kota Semarang. http://eprints.undip.ac.id/52819/1/ARTIKEL_SYAFARISCA_RAHMA_HADI.pdf

Sudarsono. 1990. Pengantar Toeri Ekonomi Mikro. LP3S. Jakarta.

Suprayitno, 2015. Faktor-Faktor Yang Mempengaruhi Pendapatan Usahatani Cabai Merah (Capsicum Annum L.) Studi Kasus Di Desa Genjor, Kecamatan Sugihwaras, Kabupaten Bojonegoro, Propinsi Jawa Timur Tahun 2015. http://ejournalunigoro.com/sites/default/files/Jurnal\%20Pak\%20Prayit.pdf

Supriadi H, Sejati W, 2018. Perdagangan Antarpulau Komoditas Cabai Di Indonesia: Dinamika Produksi Dan Stabilitas Harga. Analisis Kebijakan Pertanian, Vol. 16 No. 2, Desember 2018

http://www.ejurnal.litbang.pertanian.go.id/index.php/akp/article/view/9556

Sukirno S. 2013. Makro Ekonomi : Teori Pengantar. PT.Raja Grafindo Persada. Jakarta.

Sukmawati D, Sulistyowati L, Karmana M, Wikarta E, 2016. Fluktuasi Harga Cabai Merah Keriting (Capsicum Annum L) Di Sentra Produksi Dan Pasar Induk (Tinjauan Harga Cabai Merah Keriting Di Kecamatan Cikajang Dan Pasar Induk Kramat Jati Jakarta). Jurnal Mimbar Agribisnis Volume 1 no.2. https://jurnal.unigal.ac.id/index.php/mimbaragribisnis/article/view/58/56

Sumarsono S. 2007. Ekonomi Mikro Teori dan soal latihan. Graha Ilmu. Yogyakarta.

Swastika S, Pratama D, dkk. 2017. Buku Petunjuk Teknis Teknologi Budidaya Cabai Merah. Kerjasama UR Press dan Kementerian Pertanian Badan Penelitian Dan Pengembangan Pertanian Balai Pengkajian Teknologi Pertanian Riau

http://riau.litbang.pertanian.go.id/ind/images/stories/PDF/cabai.pdf?secure=true 